\section{Embryo Culture of Early Ripening Seeded Grape (Vitis vinifera) Genotypes}

\author{
D.W. Ramming and R.L. Emershad \\ U. S. Department of Agriculture, Agricultural Research Service, \\ Horticultural Crops Research Laboratory, 2021 South Peach Avenue, \\ Fresno, CA 93727 \\ P. Spiegel-Roy, N. Sahar, and I. Baron \\ Institute of Horticulture, Agricultural Research Organization, The \\ Volcani Center, Bet Dagan, Israel
}

Additional index words. in vitro culture, breeding, pollenizer, gibberellic acid

\begin{abstract}
Immature grape embryos from early ripening genotypes of Vitis vinifera were successfully cultured in vitro on Difco orchid agar or a modified White's agar medium. Germination was increased in vitro for five genotypes from $0 \%, 7 \%, 11 \%$, $12 \%$, and $16 \%$ in vivo to $15 \%, 24 \%, 23 \%, 34 \%$, and $24 \%$, respectively. Subculturing embryos onto liquid culture from seeds that failed to germinate on agar also was possible. Differences in germination rates, as affected by pollen, were significant. This method will allow accelerated development of early ripening cultivars by allowing breeders to use such genotypes as females, as well as males.
\end{abstract}

A major problem in developing early ripening seeded grapes is their poor germination. Balthazard (1969) found that the threshold range for successful in vivo germination in Vitis vinifera usually is attained only with embryos longer than $1 \mathrm{~mm}$. In vitro methods have been used to culture immature embryos in many crop species (Maheshwari, 1966; Raghavan, 1980; Ramming, 1983; and Tukey, 1934a, 1934b) and fertilized ovule culture has been employed successfully for interspecific cotton crosses (Stewart and Hsu, 1978).

The initial work for grapes was performed to determine if early ripening seeded genotypes could be successfully cultured in vitro

Received for publication 8 Aug. 1988. This research was supported by grant I 338-80 from the U.S.-Israel Binational Agricultural Research and Development Fund (BARD). We gratefully acknowledge the computer and statistical assistance of A. Genizi, ARO, and the technical assistance of Iris Sashitzky, ARO. Mention of trade products does not imply endorsement or recommendation over similar products not mentioned. The cost of publishing this paper was defrayed in part by the payment of page charges. Under postal regulations, this paper therefore must be hereby marked advertisement solely to indicate this fact. to enhance germination to a level useful in a breeding program (Ramming and Emershad, 1984). This report details work performed in Fresno, Calif., and Bet Dagan, Israel, on development of techniques to facilitate high production of progeny from early $\mathrm{x}$ early ripening grape crosses, including testing the effect of pollen, gibberellic acid, or daminozide on enhancement of in vitro germination in earlier-ripening genotypes.
Details of the technique used varied to some extent between the Fresno and Bet Dagan laboratories.

Cultivars. The early ripening seeded genotypes 'Early Muscat', C64-97, and C66151 were hybridized in Fresno with seedless genotypes (Table 1). Their respective soluble solids contents (SSC) and harvest dates in 1983 were: $19.0 \%$, 18 July; $18.2 \%, 18$ July; and $16.4 \%, 1$ Aug. These genotypes ripen before 'Cardinal', which had 16\% SSC on 8 Aug. 1983. 'Sivan' and 'Cardinal' were pollinated in Bet Dagan with 'Flame Seedless' and the seedless selection L-12. Seeds were harvested 25 July 1984. In 1986, in addition to 'Sivan' and 'Cardinal', experiments were performed with 'Kinnereth 2' and 'Shaharit', which ripen 1 and 2 weeks ahead of 'Cardinal', respectively. Details of harvest dates are given in Table 5. Seeds were cultured on the day of harvest.

Sterilization procedures. Fruit were harvested at maturity or somewhat later (8-25 Aug. 1983, Fresno), surface sterilized with $70 \%$ ethanol for $1 \mathrm{~min}$, then $2.63 \%$ sodium hypochlorite for $10 \mathrm{~min}$, and rinsed twice with sterile distilled water. Seeds were aseptically extracted and separated into sinkers and floaters, indicating presence or absence of endosperm, respectively. At Bet Dagan, seeds were removed in 1984 a few days before maturity; sinkers and floaters were not separated. Berries were sterilized in 1\% sodium hypochlorite for $10 \mathrm{~min}$ and triple rinsed with sterile water. The modified technique used in 1986 was to wash detached berries in a soap solution, rinse, sterilize in $70 \%$ ethanol for $5 \mathrm{~min}$, followed by $1 \%$ sodium hypochlorite for $10 \mathrm{~min}$, and triple rinse with
Table 1. Germination of seed from three early ripening grape genotypes on modified White-Norstog medium.

\begin{tabular}{|c|c|c|c|c|c|c|c|c|c|}
\hline \multicolumn{2}{|c|}{ Parentage } & \multirow{3}{*}{$\begin{array}{l}\text { Seed } \\
\text { cultured } \\
\text { (no.) }\end{array}$} & \multicolumn{4}{|c|}{ Germination } & \multirow{3}{*}{$\begin{array}{l}\text { Seedlings } \\
\text { planted } \\
\text { in field } \\
\text { (no.) }\end{array}$} & \multirow{2}{*}{\multicolumn{2}{|c|}{$\begin{array}{c}\text { Seeds } \\
\text { not } \\
\text { germinated }\end{array}$}} \\
\hline \multirow{2}{*}{$\begin{array}{c}\text { Female } \\
\text { (seeded) }\end{array}$} & \multirow{2}{*}{$\begin{array}{c}\text { Male } \\
\text { (seedless) }\end{array}$} & & \multicolumn{2}{|c|}{ Strong ${ }^{2}$} & \multicolumn{2}{|c|}{ Weak } & & & \\
\hline & & & (no.) & $(\%)$ & (no.) & $(\%)$ & & (no.) & $(\%)$ \\
\hline Early Muscat & $\begin{array}{l}\text { C89-173 } \\
\text { B46-112 }\end{array}$ & $\begin{array}{l}457 \\
622\end{array}$ & $\begin{array}{l}39 \\
63\end{array}$ & $\begin{array}{r}9 \\
10\end{array}$ & $\begin{array}{l}21 \\
34\end{array}$ & $\begin{array}{l}8.5 \\
5.5\end{array}$ & $\begin{array}{l}16 \\
39\end{array}$ & $\begin{array}{l}397 \\
525\end{array}$ & $\begin{array}{l}87 \\
84\end{array}$ \\
\hline C64-97 & $\begin{array}{l}\text { B29-82 } \\
\text { C } 67-7 \\
\text { B } 44-2\end{array}$ & $\begin{array}{r}33 \\
117 \\
45\end{array}$ & $\begin{array}{r}4 \\
26 \\
8\end{array}$ & $\begin{array}{l}12 \\
22 \\
18\end{array}$ & $\begin{array}{l}1 \\
8 \\
0\end{array}$ & $\begin{array}{l}3.0 \\
6.8 \\
0\end{array}$ & $\begin{array}{r}3 \\
21 \\
8\end{array}$ & $\begin{array}{l}28 \\
83 \\
37\end{array}$ & $\begin{array}{l}85 \\
71 \\
82\end{array}$ \\
\hline C66-151 & $\begin{array}{l}\text { B29-82 } \\
\text { Superior seedless } \\
\text { C64-150 }\end{array}$ & $\begin{array}{l}595 \\
716 \\
258\end{array}$ & $\begin{array}{r}136 \\
200 \\
43\end{array}$ & $\begin{array}{l}23 \\
28 \\
17\end{array}$ & $\begin{array}{l}2 \\
1 \\
0\end{array}$ & $\begin{array}{l}0.3 \\
0 \\
0\end{array}$ & $\begin{array}{r}118 \\
158 \\
32\end{array}$ & $\begin{array}{l}457 \\
515 \\
215\end{array}$ & $\begin{array}{l}77 \\
72 \\
83\end{array}$ \\
\hline
\end{tabular}

'Percent germination in vivo: 'Early Muscat', 0\%; C64-97, 7\%; C66-151, 16\%. Chi-square test for independence on strong germination between in vitro and in vivo: 'Early Muscat' and C64-97 significantly different at $P=0.01$; C66-151 significantly different at $P=0.05$. 
Table 2. Nongerminated grape seed that contained embryos and germinated when subcultured on liquid medium.

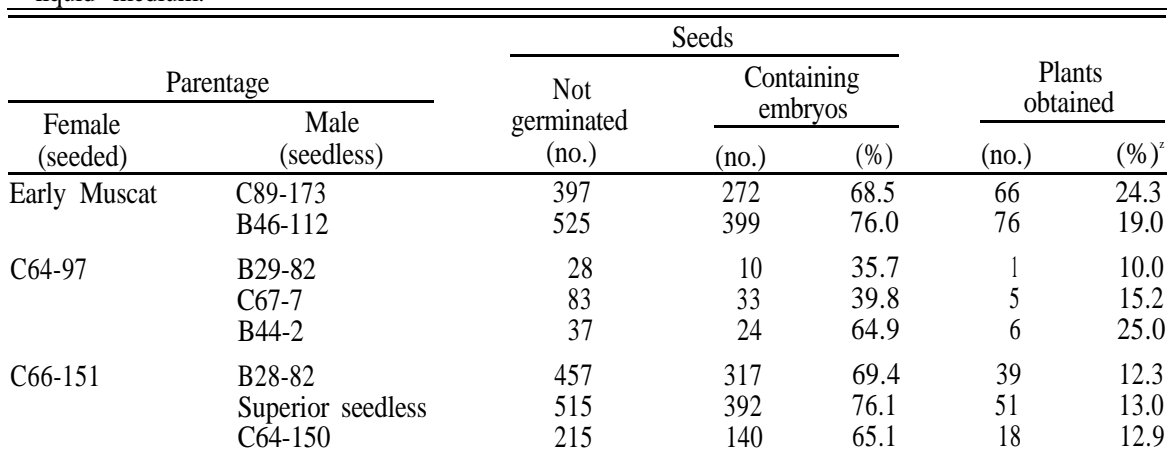

${ }^{2}$ Percent embryos grown into plants.

Table 3. Percent floaters (seed without endosperm) with embryos and number of floaters developing into plants.

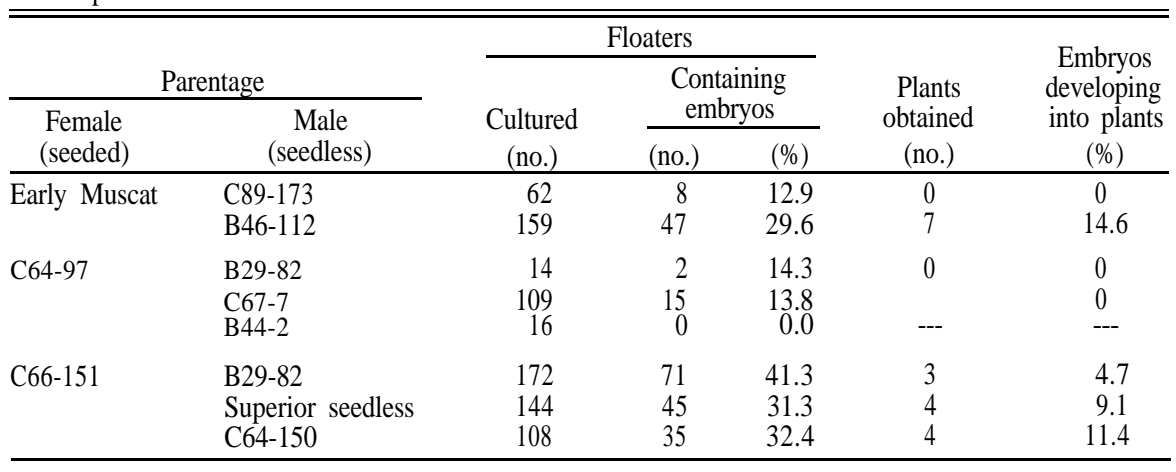

Table 4. Percent germinating embryos obtained by culturing seed of the early ripening grape cultivars 'Sivan' and 'Cardinal' on orchid agar medium in 1984. 'Sivan' pollinated 2 May and seed cultured 25 July. 'Cardinal' pollinated 29 Apr. and seed cultured 25 July.

\begin{tabular}{|c|c|c|c|}
\hline \multicolumn{2}{|c|}{ Parentage } & & \multirow{2}{*}{$\begin{array}{c}\text { Germinating } \\
\text { embryos } \\
(\%)\end{array}$} \\
\hline $\begin{array}{l}\text { Female } \\
\text { (seeded) }\end{array}$ & $\begin{array}{c}\text { Male } \\
\text { (seedless) }\end{array}$ & Treatment $^{2}$ & \\
\hline \multirow[t]{8}{*}{ Sivan } & \multicolumn{2}{|c|}{ Flame Seedless D } & $42 \mathrm{a}$ \\
\hline & & GA & $46 \mathrm{a}$ \\
\hline & & $\mathrm{OA}$ & $26 \mathrm{~b}$ \\
\hline & & In vivo & $13 \mathrm{~b}$ \\
\hline & \multirow{4}{*}{ L-12 } & D & $28 \mathrm{a}$ \\
\hline & & GA & $27 \mathrm{a}$ \\
\hline & & OA & $32 \mathrm{a}$ \\
\hline & & In vivo & $10 \mathrm{~b}$ \\
\hline \multirow{4}{*}{\multicolumn{2}{|c|}{ Cardinal Flame Seedless }} & ss D & $38 \mathrm{a}$ \\
\hline & & GA & $20 \mathrm{a}$ \\
\hline & & $\mathrm{OA}$ & $28 \mathrm{a}$ \\
\hline & & In vivo & $9 b$ \\
\hline \multirow{4}{*}{\multicolumn{2}{|c|}{ L-12 }} & D & $21 \mathrm{a}$ \\
\hline & & GA & $16 \mathrm{a}$ \\
\hline & & $\mathrm{OA}$ & $17 \mathrm{a}$ \\
\hline & & In vivo & $13 \mathrm{a}$ \\
\hline
\end{tabular}

${ }^{2} \mathrm{D}=$ daminozide $4 \times 10^{-3} \mathrm{M}$ in medium; GA $=\mathrm{GA}_{3} 10^{-6} \mathrm{M}$ in medium; $\mathrm{OA}=$ orchid agar; in vivo $=$ in vivo germination of seed from the same cross.

'Genotype and male parent were significant at $P$ $=0.05$; treatment significant at $P=0.01$. All interactions were nonsignificant. Mean separation within columns by Duncan's multiple range test, $P=0.05$. flasks with $50 \mathrm{ml}$ of medium. A filter paper support was used (Stewart and Hsu, 1978).

Seeds without endosperm (floaters) often contain embryos. This type of seed was cultured (Fresno) in 125-ml Erlenmeyer flasks with the same medium as above, except $6 \%$ sucrose was used instead of $2 \%$. The seeds were grown at room temperature for at least 3 months; then they were cut open and the embryos subcultured on the same support and medium, also with $2 \%$ sucrose.

Experiments with gibberellin and daminozide in the medium. In $1984, \mathrm{GA}_{3}\left(10^{-6} \mathrm{M}\right)$ or daminozide $\left(4 \times 10^{-3} \mathrm{M}\right)$ was incorporated in orchid agar medium and results compared to orchid agar only (Bet Dagan). Similar experiments were conducted in 1986 on two in vitro establishment dates with four genotypes.

In vivo germination comparisons. Openpollinated seed of 'Early Muscat', C64-97, and C66-151 were germinated at $27 \mathrm{C}$ in the dark after 90 days at $1 \mathrm{C}$ in $15 \times 125-\mathrm{mm}$ petri dishes with moist filter paper (Fresno). For the in vivo germination test, only sinkers were used. This procedure probably resulted in higher germination percentages in vivo than with nonseparation of sinkers from floaters, as was the case for in vitro-cultured seed at Bet Dagan, since floaters usually are devoid of endosperm and do not germinate. Seeds from crosses performed with 'Sivan' and 'Cardinal' in 1984, as well as from openpollinated seed of these cultivars and of 'Kinnereth 2' and 'Shararit' (1986), were stratified at $4 \mathrm{C}$ for 90 days. They were germinated in a 1 volcanic tuff : 1 perlite mixture (v/v) in a heated greenhouse (30C day/ 20C night) (Bet Dagan).

Plant development. Germinated plants with well-developed shoots were transplanted into soil in a greenhouse (Fresno). In the procedure used at Bet Dagan, in vitro germinating embryos that developed into seedlings were first transplanted into Magenta vessels (7.6 $\times 7.6 \times 10 \mathrm{~cm})$ in an incubator and afterward placed in a greenhouse, using the same procedure described for transplanting plantlets derived from in vitro culture of abortive ovules from seedless cultivars (Spiegel-Roy et al., 1985). Analysis of variance on germination percentage, weighted by number of seeds, was performed, followed by Duncan's multiple range test (Bet Dagan). Chisquare test for independence on germination was performed on single-tube replications (Fresno).

In vitro culture greatly enhanced the germination and production of plants from the early ripening genotypes tested. The seeds that germinated were divided into strong plants (rapidly growing plants having normal root and shoot development) and weak plants (slow-growing plants having poorly developed roots or shoots). Germination (strong plus weak) of 'Early Muscat', C64-97, and C66-151 averaged across male parents increased from $0 \%, 7 \%$, and $16 \%$ in vivo to $14.6 \%, 24.1 \%$, and $24.3 \%$ in vitro, respectively (Table 1). Nongerminating seed contained embryos in $72.8 \%, 45.3 \%$, and $71.5 \%$ of the seeds for the respective genotypes 
Table 5. Harvest date of grape cultivars and percent germination in vitro in 1986.

\begin{tabular}{|c|c|c|c|c|c|}
\hline Cultivar & $\begin{array}{c}\text { Early } \\
\text { harvest }\end{array}$ & $\begin{array}{c}\text { Germination } \\
(\%)\end{array}$ & $\begin{array}{c}\text { Late } \\
\text { harvest }\end{array}$ & $\begin{array}{c}\text { Germination } \\
(\%)\end{array}$ & Significance' \\
\hline $\begin{array}{l}\text { Shaharit } \\
\text { Kinnereth } 2\end{array}$ & $\begin{array}{l}11 \text { June } \\
18 \text { June }\end{array}$ & $\begin{array}{l}12.6 \\
60.6\end{array}$ & 18 June & $\begin{array}{l}13.2 \\
45.0\end{array}$ & 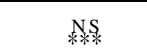 \\
\hline Cardinal & 18 June & 22.6 & 25 June & 16.7 & $* *$ \\
\hline Sivan & 1 July & 32.0 & 24 July & 41.0 & $* *$ \\
\hline
\end{tabular}

Ns, $* * * * *$ Nonsignificant or significant at $P=0.01$ or 0.001 , respectively.

Table 6. Germination of embryos obtained by culturing seed of the early ripening cultivars Shaharit, Kinnereth 2, Sivan, and Cardinal on orchid agar medium with and without supplements.

\begin{tabular}{lcccr}
\hline \hline & \multicolumn{4}{c}{ Cultivar $^{y}$} \\
\cline { 2 - 5 } Supplement & Shaharit & Kinnereth 2 & Sivan & Cardinal \\
\cline { 2 - 5 } & & Germination $(\%)$ & $15.3 \mathrm{~b}$ \\
None & $15.8 \mathrm{a}$ & $51.0 \mathrm{ab}$ & $33.7 \mathrm{a}$ & $31.7 \mathrm{a}$ \\
$\mathrm{GA}_{3}, 10^{-6} \mathrm{M}$ & $14.0 \mathrm{ab}$ & $61.8 \mathrm{a}$ & $39.0 \mathrm{a}$ & $13.5 \mathrm{~b}$ \\
Daminozide, $4 \times 10-^{3} \mathrm{M}$ & $9.2 \mathrm{~b}$ & $44.0 \mathrm{~b}$ & $37.6 \mathrm{a}$ & \\
\hline
\end{tabular}

${ }^{7}$ Only well-developed germinating plants were counted, final count made on 24 Dec. 1986.

'Mean separation within columns by Duncan's multiple range test, $P=0.05$.

(Table 2). These embryos were subcultured, and $21.2 \%, 17.9 \%$, and $12.7 \%$ germinated and then were planted in the greenhouse. When the number of strong and weak seed germinations in test tubes and the number of excised embryos germinating in liquid culture were combined, the total germination was increased by $27.7 \%, 23.3 \%$, and $15.2 \%$, compared to germination in vivo.

Floaters that were cultured had embryos in $24.9 \%, 12.2 \%$, and $35.6 \%$ of the seeds from 'Early Muscat', C64-97, and C66-151, respectively, and, when subcultured, they produced seven, zero, and 11 plants in the greenhouse (Table 3). Embryo size in the floaters after culture was larger in some cases than embryos in the nongerminating sinkers at culture termination. This difference may be due to restriction of growth caused by the endosperm confining the embryo to a limited space.

In experiments performed in Bet Dagan, the percentage of germinating embryos from seed of 'Sivan' was higher than from 'Cardinal' (Table 4). Germination percentage with seed of both genotypes was significantly higher when flowers were pollinated by 'Flame Seedless' than by L-12. Neither gibberellic acid $\left(\mathrm{GA}_{3}\right)$ nor daminozide in the medium significantly affected germination rates in vitro relative to in vivo germination.

Cultured seed in orchid agar showed significantly higher germination when compared with in vivo germination of seed derived from the same controlled pollination (Table 4). Germination in vitro with 'Sivan', compared to in vivo, was increased by $13 \%$ to $22 \%$ (according to pollenizer), while increases with 'Cardinal' were between $4 \%$ and $19 \%$ (according to pollenizer).

There was only a 1-week difference between early and late harvest dates for 'Shaharit' and 'Cardinal' (Table 5). A longer period elapsed between the first and second harvest dates for the two other cultivars (Table 5). In 'Kinnereth 2' and 'Cardinal', a higher germination percent of cultured seeds was obtained with the earlier date. With
'Shaharit', there was no difference between the two dates. With 'Sivan', late harvest gave significantly better results than earlier harvest. Counts of germinating embryos were made on 24 Dec. 1986, although some additional seed germinated after final counts were also noted. In vivo germination (after exposure of seeds to moist stratification at 4C for 90 days) in 1986 for three early maturing cultivars was $4 \%$ for 'Sivan', $0 \%$ for 'Shaharit', and $1 \%$ for 'Cardinal'. 'Kinnereth 2 ' germination in vivo was $25 \%$. Average in vivo germination for 4 years was $10 \%$ for 'Sivan', $13 \%$ for Cardinal', and $29 \%$ for 'Kinnereth 2'. No in vivo germination of 'Shaharit' was obtained in either 1985 or 1986.

When four genotypes and three media (orchid agar and additions of either $\mathrm{GA}_{3}$ or daminozide to the medium) were tested in 1986, good in vitro germination rates were obtained with 'Kinnereth 2' and 'Sivan' (Table 6), with the latter being more than eight times higher than the in vivo rate of 1986. In 'Shaharit' and 'Cardinal', fair germination rates were obtained in vitro, compared with no germination in vivo. In 'Cardinal', addition of $10^{-6} \mathrm{M} \mathrm{GA}_{3}$ to the medium doubled germination rates, compared to the orchid agar control. However, with the three other cultivars, no significant increase in germination was obtained by the addition of $\mathrm{GA}_{3}$. Inclusion of daminozide, a gibberellin antagonist, resulted in significantly lower germination in 'Shaharit'. With 'Cardinal', as with 'Sivan' and 'Kinnereth 2', results with daminozide were similar to the orchid agar check, but significantly inferior to orchid agar $+\mathrm{GA}_{3}$.

Successful in vitro embryo rescue from early ripening seeded cultivars was developed using media without phytohormones. Addition of indoleacetic acid and gibberellic acid to the medium was essential for the in vitro culture of embryos from seedless genotypes (Spiegel-Roy et al., 1985). In the present experiments related to culture of embryos from seeded genotypes, addition of $\mathrm{GA}_{3}$ to agar gave better results only with 'Cardinal' in 1 out of 2 years. Gibberellic acid has been found to substitute for chilling requirement in experiments in culturing immature peach embryos (P. S.-R., unpublished).

Media for continued development of embryos differed to some extent between Fresno and Bet Dagan. Modified White-Norstog medium with added microelements, vitamins, minerals, glycine, casein hydrolysate, and sucrose in agar have been used at Fresno; orchid agar was used at Bet Dagan. In both cases, increased germination over in vivo resulted. Germination was achieved in vitro for two genotypes, 'Early Muscat' and 'Shaharit', which do not germinate in vivo. Seeds were chilled for 45 days in the media before germination because, in experiments not reported here, nonchilled seeds did not germinate. We also found that embryos could be extracted from nongerminated seed, and, when cultured on liquid medium with a filter paper support, yielded plants.

Contradictory results were obtained as to the relation of time of harvest and initiation of cultures to the rate of in vitro germination. In two out of four cultivars, earlier seed harvest proved advantageous; in one, no significant difference between early and late harvest was found; and, in one cultivar, later harvesting was preferable for culturing.

Significant increases in germination of early ripening grape genotypes were achieved by in vitro relative to in vivo culture of embryos; with 'Cardinal' and 'Sivan', the increases were $15 \%$ and $30 \%$, respectively. With 'Early Muscat' and two early ripening selections that ripen before 'Cardinal', gains in germination of $8 \%$ to $15 \%$, compared to in vivo germination, were obtained.

One of the early ripening seeded grape cultivars Shaharit (14 to 25 days before "Cardinal') has yielded up to $16 \%$ germination in vitro in agar, compared to no germination in vivo during several seasons. As time of fruit maturity has been found to be under polygenic control (Spiegel-Roy et al., 1981), use of embryo culture should: 1) aid considerably in breeding for early ripening in grapes, 2) eliminate widespread fluctuations in availability of progenies from early ripening genotypes, and 3) facilitate efficient handling and growing of many progenies from such genotypes, thus increasing chances of obtaining superior early ripening seedless cultivars.

\section{Literature Cited}

Balthazard, J. 1969. Temperatures alternées, longueur des embryons et pouvoir germinatif des graines de Vigne. Compt. Rend. Hebd. Séances Acad. Sci. 269:2355-23.58.

Knudson, L. 1946. A new nutrient solution for the germination of orchid seed. Amer. Orchid Soc. Bul. 15:214.

Maheshwari, P. 1966. The embryology of angiosperms-A retrospect and prospect, p. 97112. In: E.G. Cutter (ed.). Trends in plant morphogenesis. Longmans, London.

Norstog, K. 1973. New synthetic medium for the culture of premature barley embryos. In Vitro 8:307-308.

Raghavan, V. 1980. Embryo culture. Intl. Rev. 
Cyt. Suppl. II:209-240.

Ramming, D.W. 1983. Embryo culture, p. 136144. In: J.N. Moore and J. Janick (eds.). Methods of fruit breeding. Purdue Univ. Press, West Lafayette, Ind.

Ramming, D.W. and R.L. Emershad. 1984. Embryo culture of early-ripening seeded grape genotypes. HortScience 29:594. (Abstr.)

Spiegel-Roy, P., R. Assaf, and I. Baron. 1981.
Inheritance of some characters in progenies of Vitis vinifera from crosses with Dabouki and Alphonse Lavallee. Proc. 3rd Intl. Symp. on Grape Breeding, Davis, Calif. p. 210-219.

Spiegel-Roy, P., N. Sahar, I. Baron, and U. Lavi. 1985. In vitro culture and plant formation from grape cultivars with abortive ovules and seeds. J. Amer. Soc. Hort. Sci. 110:109-112.

Steward, J.M. and C.L. Hsu. 1978. Hybridization of diploid and tetraploid cottons through in ovulo embryo culture. J. Hered. 69:404-408.

Tukey, H.B. 1934a. Artificial culture of sweet cherry embryos. J. Hered. 24:7-12.

Tukey, H.B. 1934b. Artificial culture methods for isolated embryos of deciduous fruits. Proc. Amer. Soc. Hort. Sci. 32:313-322.

White, P.R. 1954. The cultivation of animal and plant cells. Ronald Press, New York. 